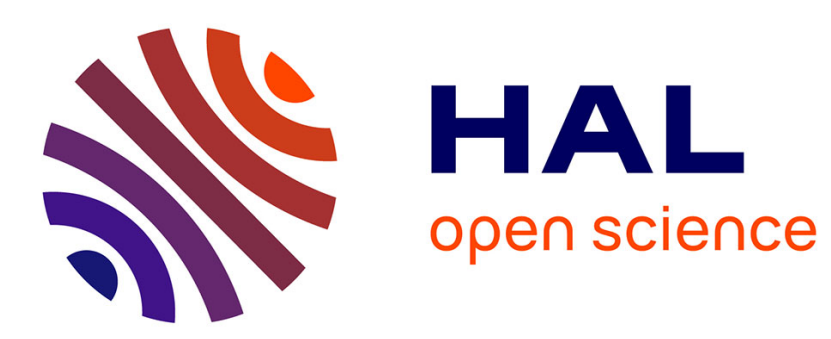

\title{
Cantillon and Hume on money and banking: the foundations of two theoretical traditions
}

\author{
Laurent Le Maux
}

\section{To cite this version:}

Laurent Le Maux. Cantillon and Hume on money and banking: the foundations of two theoretical traditions. Journal of Economic Surveys, 2014, 28 (5), pp.956-970. hal-01397052

\section{HAL Id: hal-01397052 \\ https://hal.science/hal-01397052}

Submitted on 16 Nov 2016

HAL is a multi-disciplinary open access archive for the deposit and dissemination of scientific research documents, whether they are published or not. The documents may come from teaching and research institutions in France or abroad, or from public or private research centers.
L'archive ouverte pluridisciplinaire HAL, est destinée au dépôt et à la diffusion de documents scientifiques de niveau recherche, publiés ou non, émanant des établissements d'enseignement et de recherche français ou étrangers, des laboratoires publics ou privés. 


\title{
CANTILLON AND HUME ON MONEY AND BANKING: THE FOUNDATIONS OF TWO THEORETICAL TRADITIONS
}

\author{
Laurent Le Maux* \\ January 2014
}

\begin{abstract}
The distinction between the 'classical' monetary theory and 'quantity' theory has been proposed in literature on money and banking. The overall feature of the classical theory of money is that it holds one principle of regulation for each kind of issue (metallic money, bank issues and paper money) whereas the quantity theory applied the causality and proportionality postulates for all kinds of monies. Without claiming to adjudicate the validity of such a distinction, the paper investigates the foundation of each tradition. In this respect, this paper, respectively, examines, and provides a survey of the secondary literature on, Cantillon's Essai and the Hume's Discourses.
\end{abstract}

\section{Introduction}

Richard Cantillon's Essai sur la Nature du Commerce en Général and David Hume's Political Discourses have aroused interests among the monetary economists from the 1930s onwards and they have generated new interpretations and debates during the three last decades. ${ }^{1}$ On the one hand, Hayek (1931) thought that the Discourses was so close to the Essai that Hume could have read Cantillon's manuscript, even if there is no evidence that he knew it. On the other hand, Adam Smith referred by name to Cantillon in the Wealth of Nations and proposed a theory of the value of metallic money and the regulation of bank issues that may also be found in the Essai. Furthermore, Smith did not restate Hume's price-specie-flow mechanism and even explicitly rejected Hume's theory of bank notes. If Discourses and Wealth of Nations are both similar to the Essai, how, then, could they be so different? One way of approaching this problem, evoked by Viner (1937), has been to imagine Smith's nonadherence to Hume's analysis as a 'mystery'.

* Professor in economics, University of Brest and University of Paris Saint-Denis, France. The present paper will be published in the Journal of Economic Surveys, 28(5), 2014. 
Another way, suggested here, is to investigate whether the Essai is mostly dissimilar with the Discourses and announced the theoretical framework that the Wealth of Nations fell under. Indeed, the Essai and the Discourses differ in important respects in their treatment of the value of metallic money and more obviously as regards the regulation of bank issues. The Essai and the Discourses are not only different, but could have even inaugurated two theoretical traditions, respectively, the 'classical' theory of money later espoused by Smith (1776) and the Banking School (Mill, 1844; Tooke, 1844, 1848; Fullarton, 1845), and the 'quantity' theory of money supported by Ricardo $(1810,1811,1817)$ and the Currency School (Joplin, 1844; Loyd, 1840, 1844; Torrens, 1844, 1848).

The distinction within the Classical Economics between the 'classical' monetary theory and the 'quantity' theory has been drawn by Niehans $(1978,1987,1990)$, Glasner $(1985,1989,2000)$ and Skaggs $(1991,1994,1995)$ - the latter reference studying Thornton's (1802) monetary analysis. The overall feature of the classical monetary theory is that it proposes one principle of regulation for each kind of issue (specie money, bank issues and inconvertible paper money). As this paper will detail, the cost-of-production theory explains how the value of metallic money and the price level are determined by cost conditions. The law of reflux, which ultimately takes the form of convertibility, explains how the value of demand debts equates to the face value of ultimate money. The quantity postulates of causality and proportionality are only called upon by the classical monetary theory in the case of debasement and cautiously in the case of the supply of inconvertible paper money. In contrast, the feature of the quantity theory of money is the reasoning in terms of the aggregation of all kinds of 'monies' (specie money, bank money and inconvertible paper money) and the application of the causality and proportionality postulates in all cases, irrespective of the kind of issue, the monetary aggregate, or the monetary regime. The distinction between the classical monetary theory and the quantity theory has been discussed by Blaug (1995) and O'Brien (1995) with a response from Glasner (2000). Without pretending to adjudicate the validity of such a distinction, I believe that it is worthwhile to investigate the foundation of each tradition.

In this perspective, Section 2 examines Cantillon's Essai and Hume's Discourses on metallic currency and the dynamic of the balance of trade. They present a similarity with respect to the concept of endogenous money through a trade surplus, but diverge since Cantillon proposed the cost-of-production theory of the value of metallic money and never mentioned the case of exogenous money. Section 3 is concerned with the marked difference between Cantillon and Hume on the question of the monetary role of bank issuing. Cantillon developed the law of reflux and the proposition that banks contribute to accelerating the circulation of money (hereafter, the banking approach of circulation), whereas Hume developed the quantity theory applied to bank notes and the proposition that banks multiply the quantity of money (hereafter, quantity approach of banking). The historical context and the practice of 
the option clause by Scottish banks in the 1760s partly explain Hume's confusion between convertible bank notes and inconvertible paper money - confusion typical of the quantity theory. In conclusion, this paper suggests that, beyond the historical context, the Cantillon-Hume opposition on money and banking inaugurated the controversy between the classical monetary theory and the quantity theory. For an overview of the concepts used in the paper, the reader may refer to the table in the Appendix.

\section{The Metallic Money}

Cantillon and Hume are regarded as precursors, either of the price-specie-flow mechanism, or of the monetary approach to the balance of payments. Both approaches deal with international-reserve-flow mechanism. The price-specie-flow mechanism views the movements of precious metals as a consequence of relative price changes between countries. Money is exogenous in the sense that a shock, say a sudden increase, in the domestic money supply is presupposed. Any excess in the quantity of money then initiates a proportional rise in prices (quantity theory) and the ensuing change in relative prices causes a decline of the competitiveness of domestic products (violation of the law of one price). The ensuing outflow of precious metals decreases domestic prices, therefore prompting a return to equilibrium (automatic adjustment). In the secondary literature, Cantillon and Hume are sometimes listed among the proponents of the price-specie-flow mechanism as a self-equilibrating adjustment. $^{2}$

The monetary approach to the balance of payments describes the movements of international reserve as adjustments of quantities and not of relative price levels. The balance of payments and the flows of international reserves are governed by monetary forces reflecting domestic disequilibrium between the demand for and the supply of money (Johnson, 1972, 1976; Frenkel and Johnson, 1976). Money is viewed as endogenous in the sense that the amount of money in an economy is automatically adjusted to the demand through surpluses or deficits in the current balance. Any excess supply of money in a country is withdrawn from circulation through the balance of payments without affecting relative price levels of domestic and foreign goods. The law of one price is thus supposed to be effective in that two similar commodities offered for sale in two different places at the same time sell at the same price. In the secondary literature, Cantillon and Hume are sometimes thought to have espoused the law of one price and to have anticipated the monetary approach to the balance of payments. ${ }^{3}$

At first, I shall indicate how Cantillon dealt only with endogenous money in the sense that the production of precious metal and the value of metallic money are 
determined by cost conditions (Section 2.1). Then, I shall restate the analytical distinction emphasised by Niehans (1978) between exogenous and endogenous money in Hume's writings (Section 2.2). Moreover, Wennerlind (2005) explains that an exogenous increase generates a proportional rise in prices without any effect on output (neutrality of money) and an endogenous increase in the money supply generates positive effects on output (non-neutrality of money). The distinction between endogenous and exogenous money goes beyond the distinction in the literature on Humean monetary analysis between short-term non-neutrality and long-term neutrality.

\subsection{Cantillon's Model of Endogenous Money}

By money, Cantillon meant the silver or gold specie coined at an official price at the Mint. Specie is the only form of money (qualified by an adjective such as 'real' or 'actual') and Cantillon disapproved of inconvertible paper money (which he held to be 'fictitious' and 'imaginary'). In his mind, ultimate money could not be paper money but specie alone. Hence, in the context of the specie regime, the Essai upholds the theory whereby the value of money depends on its cost of production, and not on its quantity. In Cantillon's words, the 'real or intrinsic value' of a precious metal, like that of any other commodity, is 'proportionable to the land and labour' that enters into its production (Essai, p. 97). The value in exchange for other merchandise is 'necessarily fixed by that which was put upon it at the new mine' (Essai, p. 101). In modern terms, the exchange is adjusted to the cost of the marginal mining product. Finally, it depends on extraction, production and transportation costs on the one hand, and on the 'humour of men' on the other hand (Essai, pp. 175, 273, 277).

Importantly, the cost-of-production theory means that metallic money entered endogenously in the market with a value. The causality goes from price to supply of the metallic money and the proportionality postulate of the quantity theory is at best a very particular case and not the general theory of the value of metallic money. Cantillon (Essai, pp. 163, 167, 181) was aware that an increase in the quantity of money triggered by new mines or trade surplus induces an increase in expenditure and finally in the price level, but he did not go so far as to adhere to the quantity theory and its proportionality postulate. Indeed, the price rise caused by new supply of specie 'does not affect equally all the kinds of products and merchandise, proportionally to the quantity of money'. (Essai, p. 181; pp. 161, 177). The modern formulation given by Niehans $(1978$, p. 147) concludes that the quantity theory of money does not strictly apply under the commodity money regime: 'While gold discoveries will certainly tend to push prices up, it would be a coincidence if the money supply and commodity prices moved up in proportion'. Such a coincidence refers to a unit-elastic non-monetary demand for precious metal. Niehans (1987, p. 413) continues: "Value theory and monetary theory are fully integrated, and the quantity of money adjusts passively, through production or foreign trade, to whatever 
is demanded. From this point of view, classical writers like Cantillon and Adam Smith were right in denying any strict proportionality of money and prices'. Finally, Niehans (1987, p. 411) regards Cantillon as the 'founder of classical monetary theory' - to which Smith (1776), Senior (1840), Tooke (1844, 1848) and Fullarton (1845) contributed afterwards - in opposition to the 'quantity theory of money'.

Cantillon (Essai, p. 181) posited the following endogenous channels (listed in order of increasing importance): subsidies paid from foreign countries, extraction from new mines of precious metals in the state, 'but above all', by a regular trade surplus. 'It is by this last means that a state grows most substantially, especially when its trade is accompanied and supported by ample navigation and by considerable raw produce at home'. Thus, above all, the commercial power of the state and improvement in industrial production initiate a trade surplus and cause an endogenous supply of money. This 'increase of money will enrich a great number of merchants and undertakers in the state, and will give employment to numerous [craftsmen] and workmen who furnish the commodities sent to the foreigner from whom the money is drawn. This will increase gradually the consumption of these industrial inhabitants and will raise the price of land and labour' (Essai, p. 167) - and, as noted above, this increase will not be proportional. Then, in the foreign countries, where money is rare, cheapness of commodity and labour cause 'the erection of manufactories and works similar to those of the state, but which will not at first be so perfect nor so highly valued' (Essai, p. 169, added italics); and 'though these new establishments of crafts and manufactures be not at first perfect they slacken and even prevent the exportation of those of the neighbouring state into their own country where they can be got cheaper'. (Essai, p. 183, added italics). So, the technological advance, industrial improvement and commercial reputation of the state endogenously initiate a dynamic adjustment in the balance of trade and flows of precious metals. Then, price-competition from foreign countries whose products, however, are not so perfect, diminishes to some extent the trade surplus of the state, without reversing the balance of trade for a long period of time and therefore without entailing a trade deficit. 'The articles and manufactures of the state having a great reputation, and the facility of navigation affording the means of sending them at little cost into distant countries, the state will for many years keep the upper hand over the new manufactures [of foreign countries] and will still maintain a small balance of trade' (Essai, p. 183, added italics). A trade surplus is not automatically absorbed and is maintained so long as the state enhance its industrial and commercial activity. In this line of interpretation, Gillard (2011, pp. 359-360) also argues that an automatic mechanism is not strictly stipulated in the Essai.

Thus, Cantillon's analysis is significantly different from the price-specie-flow mechanism. Metallic money is supplied endogenously, through the production of mines and by way of a surplus in the balance of trade. Unlike Hume in his Discourses, Cantillon never posited an exogenous change in the quantity of metallic money or in the quantity of bank issues. 


\subsection{Hume's Models of Exogenous and Endogenous Money}

Hume proposed two models of specie-flow mechanism, one with an exogenous change and the other with an endogenous change in the quantity of money. The literature has mainly retained the model with exogenous money. At first, I shall present the two models proposed by Hume. Then, I shall review the literature that draws the distinction between exogenous and endogenous money in Hume's writings. Finally, if the model with endogenous money is more appropriate to the specie regime that Hume studied in his time, it may be also pointed out that Hume, unlike Cantillon, did not integrate the cost-of-production theory into his monetary theory.

In the first model, Hume told the famous overnight story in which the quantity of specie suddenly changes 'by miracle' and 'in one night' in a state (Discourses, pp. 299, 311; Hume, 1749 [1955], pp. 188- 189). The exogenous increase in the stock of metallic currency generates a proportionate rise in domestic prices, a stimulus of importations and a fall in exportations until the appearance of a trade deficit and an external drain of precious metals. Oscillatory movements of relative prices and corresponding flows of metallic currency provide an automatic adjustment of the distribution of precious metal among countries and restore the level of money to its original equilibrium. This is the price-specie-flow mechanism. But what should have been taken as a simple supposition nevertheless contributed to obscuring another aspect of Hume's analysis. In the second model, indeed, Hume studied the case of the specie inflows resulting from trade surplus, that is, "when any quantity of money is imported into a nation', when the increase of money is 'not too sudden' (Discourses, pp. 286-287; Hume, 1750 [1955], pp. 197-198). The endogenous increase in the supply of money induced by a trade surplus depends on the economic growth and productivity, that is, when a nation has got a 'superior industry and skill' (Discourses, p. 283), when an 'encrease of its art and industry' occurs (Discourses, p. 314), since 'every thing must become much cheaper in times of industry and refinement' (Discourses, p. 291). In addition, 'the prices of every thing depend on the proportion between commodities and money' (Discourses, p. 290) and the proportion between money holding and output is at an equilibrium level (Discourses, p. 315n). Finally, Hume's second model with industrial improvement and endogenous money has been encapsulated by Wennerlind (2005, pp. 228-229) in these terms: 'improvements in industry lower domestic prices and $[\ldots]$ the adjustment process whereby gold flows in and goods flow out $[\ldots]$ continues until the proper proportion between circulating money and marketable commodities is re-established'. (See also, Berdell, 1995, pp. 1208-1209; Paganelli, 2006, pp. 538-539.)

Some authors thus emphasise that Hume should not be suspected of unconditionally adhering to the price-specie-flow mechanism. Niehans (1987, pp. 413-414) spells out that, in the first model, Hume 'suggested a mental experiment in 
which gold coins are treated as if they could be miraculously created or annihilated; thus he obtained the proportionality proposition' (original italics). However, in the second model, Hume 'went to great lengths in explaining that, in reality, money is supplied endogenously through gold mining and international specie flows'. Unfortunately, the first model 'became the point of departure for the secondary offshoot of the classical tradition'. Cesarano (1998, pp. 177-179) argues that the overnight story was just a 'thought experiment' motivated by the Humean attitude against mercantilism that aimed 'to prove the stability result' in the case of a change in relative prices; on the other hand, a close formulation of the 'law of one price' is believed to be detected in a passage from Hume (Discourses, pp. 314-315) on the equal proportionality between money and output from one place to another; thus, it is inferred that Hume's second model appears to have anticipated the monetary approach to the balance of payments. Wennerlind (2005, p. 230) differentiates between exogenous and endogenous money supply and thus two facets of the Hume's quantity theory: exogenous money is regulated by the 'simple quantity theory' used in the price-specie-flow mechanism; the regulation of the endogenous money supply bears 'a greater resemblance to the quantity theory of money used in the monetary approach to the balance of payments'.

It is a controversial question as to whether or not Cantillon and Hume had recognised the law of one price - and hence the monetary approach to the balance of payments - especially concerning Hume (Fausten, 1979; Cesarano, 1998; Schabas, 2008). A few comments seem here necessary. First, Cantillon and Hume were aware of transportation costs: indeed, the domestic price of traded goods can only be raised above the price in other countries 'by the cost and risk of importing' traded goods (Essai, p. 179); and the circumstance that 'can obstruct' the similarity of the price level in every country is 'the expense of transporting the commodities' and 'this expense is sometimes unequal' (Discourses, p. 315n). Secondly, whatever the level of transportation costs, Hume's first model that assumes an exogenous change in the quantity of money does not need the violation of the law of one price to derive the stability result that Hume was aiming to prove (Samuelson, 1980). Thirdly, Hume's second model that assumes an endogenous change in the quantity of money through a trade surplus does not fail by disregarding the law of one price, but more fundamentally by endorsing the quantity theory in the case of metallic money. The monetary regime that Cantillon and Hume examined at their time, that is, the specie regime, was quite different from the monetary regime that proponents of the monetary approach to the balance of payments attempted to grasp in the 1970s, that is, the regime of inconvertible central bank money (fiat money) with a fixed exchange rate. The quantity theory endorsed by Hume or the proponents of the monetary approach might be called upon in the case of the fiat money regime (with or without fixed exchange rate), but it remains unsuitable in the case of the specie regime. In other words, the confusion between the two kinds of monetary regimes makes sense within the quantity tradition (which amalgamates the specie regime and the fiat 
money regime), but it makes no sense within the classical monetary tradition (which applied different principles for each kind of monetary regime).

Therefore, the monetary regime and the related theoretical framework proposed by Cantillon and Hume appears at first more fundamental than the application (or not) of the law of one price during the process of adjustment. Some commentators pointed out that there might be an inconsistency in Hume's position of not maintaining the cost-of-production theory. For Marx (1859, [1970], p. 164), Hume considered that "commodities without price and gold and silver without value enter the process of circulation' and therefore he 'never mention[ed] the value of commodities and the value of gold, but sp[oke] only of their reciprocal quantity'. Niehans (1990, p. 54) shares a similar view in stating that Hume treated commodity money 'as if' it was fiat money (original italics). Hume (1769 [1955], p. 214) recognised more than a decade after his Discourses that 'money must always be made of some materials, which have intrinsic value', but he did not correspondingly amend his second model. Thus, despite the fact that Cantillon's model and Hume's second model both made the assumption of endogenous money, a divergence may be underlined: Cantillon integrated into his models that specie enters into circulation with any value, whereas Hume did not. Furthermore, Cantillon's theory and the classical monetary theory may include the transportation costs of the precious metal and that of other goods in their respective value. Finally, the concept of endogenous money developed by the classical monetary theory differs from the monetary approach to the balance of payments: it is based on the cost-of-production theory and the law of reflux. The quantity theory is called upon once gold or silver coins are debased or inconvertible paper circulates within the state.

The theoretical distinction setting the classical monetary theory (the cost-ofproduction of the value of the metallic money) against the quantity theory (the causality and proportionality postulates irrespective of the kind of monies) appears fundamental in the case of the specie regime. Another distinction might complete the overall picture by setting the 'metallism' view (according to which money would originally consist of some commodity) against the 'convention' view (according to which money is above all a convention). Cantillon might be suspected of having adopted the metallism view. Caffentzis $(2001,2008)$, Wennerlind $(2001,2008)$ and Desmedt (2008) have accurately shown that Hume adopted the convention view. It may be added that, once the specie regime is supposed, the introduction of cost-ofproduction theory does not necessarily equate to unconditional support of the metallism view. The authors of the Banking School adopted the convention view in general and the cost-of-production theory under the specie regime in particular, at the same time. In other words, the adoption of the convention view does not absolve Hume from theoretical misconception, such as the adoption of the quantity theory in the case of metallic money - and in the case of convertible bank notes as well. 


\section{The Monetary Role of Bank Issuing}

In the late 17th and early 18th century, banks in London and Britain began to put deposit certificates, bank notes or demand deposits into circulation, which were all convertible at request at face value into specie but not fully backed by metallic reserve, that is, all of which are means of payment that are defined as demand debts. The question was whether banks had a monetary role and, if so, how that role could be analysed. Cantillon and Hume explored two opposite answers: Cantillon suggested that bank issuing involves an acceleration of the circulation of money (hereafter, the banking approach of circulation) and Hume that it corresponds to a multiplication of the quantity of money (hereafter, the quantity approach of banking).

Before describing these two approaches and because Cantillon's banking approach of circulation is not familiar, clarification is required here. Cantillon held two propositions on the circulation of money. The first and well-known proposition states that a change in the velocity of money among the public is equivalent to a change in its quantity. If Petty (1664 [1899], pp. 112-113) and Locke (1691 [1823, p. 23]) touched on the idea of velocity of circulation of money, Cantillon (Essai, p. 161) was the first to postulate that 'an acceleration or greater rapidity in circulation of money in exchange, is equivalent to an increase of actual money up to a point'. It is a monetary concept inasmuch as it may apply to money without needing reference to the issuing activity of banks. Cantillon's banking approach of circulation is the second proposition distinct from the first one. As I shall detail, it is a banking concept inasmuch as it necessarily involves banks as issuers of demand debts. ${ }^{4}$ The quantity approach of banking set out by Hume remains far more familiar in the monetary literature and has no doubt overshadowed the banking approach of circulation proposed by Cantillon. It mainly rests on a threefold feature that may be found in the Discourses, including (i) the aggregate of 'base money' and 'bank money', (ii) the money multiplier linking the two and (iii) the application of the quantity theory to the monetary aggregate. ${ }^{5}$

After a presentation of Cantillon's theory of bank issuing (Section 3.1), I shall compare the analysis by Hume and Cantillon of bank issue and describe the historical Scottish banking practice known as the option clause in order to better understand Hume's confusion between bank notes and inconvertible paper money (Section 3.2).

\subsection{Cantillon on Banks as Accelerators of the Circulation of Money}

Under the institutional design studied by Cantillon, a bank is fractional-reserve institution holding money, that is, an institution issuing demand debts such as bank notes or demand deposits convertible at face value into and partially backed by specie money. Cantillon (Essai, p. 305) underlined that the form of demand debt is only a 
practical matter: the advantage of demand deposits is that unlike bank notes, they are not subject to counterfeiting; the drawback is that people in the suburbs and a fortiori people in the country 'at a distance from the bank will rather pay and receive in money than to go thither' and, by contrast, 'if the bank notes are dispersed they can be used far and near'. The form of bank issue is a practical matter, not a theoretical matter.

The Essai states a proposition, termed here the banking approach of circulation, which analyses the effect of bank's issue on the circulation. As long as demand debts issued by banks remain convertible at face value and circulate instead of money, they accelerate circulation of money. In this respect, two excerpts are decisive. The 'bankers, whose notes pass current in payment like ready money, contribute also to the speed of circulation, which would be retarded if money were needed in all payments for which these notes suffice' (Essai, pp. 141-143, added italics). They 'contribute to accelerate $[\mathrm{sic}]$ the circulation of money. They lend it out at interest at their own risk and peril, and yet they are or ought to be always ready to cash their notes when desired on demand'. (Essai, p. 301, added italics; p. 305). The distinction between specie money and convertible bank notes stands for a precise articulation between them: demand debts accelerate the circulation of money, which would be delayed if they were not issued. By accelerating the velocity of money, banks bear a credit risk at the same time (banks lend 'at interest at their own risk and peril') and a liquidity risk (they have to reimburse their issues 'when desired on demand'). By analogy, money and bank issue may not be equivalent, just as the sailboat may not be equivalent to the wind that helps it to go faster.

Once Cantillon's banking approach of circulation is conveyed, one question is to know how demand debts are regulated and whether the acceleration of money they induce is contained and does not entail inflation. Cantillon (Essai, p. 303) implicitly answered by mentioning the reflux in the form of demand for convertibility of bank notes into specie and the mechanism by which competing issuing banks are compelled to reimburse every note in excess. The constraint of reflux implies that bankers 'will be ruined in credit if they fail for one instant to pay their notes on their first presentation, and when they are short of cash in hand they will give anything to have money at once, that is to say a much higher interest than they receive on the sums they have lent'. In modern terms, the marginal cost of redeeming unwanted bank notes or demand debts exceeds the marginal gains from issuing them so that banks are discouraged to pursue an overissue policy. The speed of the regulation depends on the channel by which bank notes are returned to the issuer. On the one hand, the public returns notes they do not wish to hold by asking them for specie: if notes issued by a banker 'fall into the hands of persons who are not accustomed to deal [sic] with him', they stay in circulation for longer and this delays their payments 'a few days or weeks'. On the other hand, and more drastically, rival banks impose discipline with respect to bank issues and speed up the reflux: if 'his notes come into 
the hands of those of his own business', these rival bankers 'will have nothing more pressing than to withdraw the money from him' (Essai, p. 303). The law of reflux here formulated explains the endogeneity of the supply of demand debts - which is different from the endogeneity of the supply of money resulting from the state of the balance of trade or the condition of production of the precious metal.

As seen in Section 2.1, Cantillon rejected the proportionality postulate of the quantity theory in the case of metallic money and he did not explicitly mention it in the case of inconvertible paper money. Debasement, that is, an alteration of the monetary convention, and not a change in the quantity of money, is the sole case in which Cantillon (Essai, p. 113) explicitly referred to the proportionality postulate. In addition, Cantillon (Essai, p. 311) treated specie and inconvertible paper money as having an effect on prices: 'abundance of fictitious and imaginary [paper] money' and 'an increase of real [metallic] money in circulation' cause the same effect 'by raising the price of land and labour'. As seen in Section 3.1, the reflux of bank issues is fast enough (taking only a few 'weeks' at most) to avoid overabundance and inflation. Hence, Cantillon's monetary theory treats bank notes very differently from inconvertible paper money, which in contrast produces inflationary effects. By formulating the law of reflux, Cantillon also established the foundation of the classical monetary theory in opposition to the quantity theory. Afterwards, within the classical monetary tradition, Adam Smith and the Banking School challenged the Humean and Currency School's quantity approach to money and banking.

\subsection{Hume on Banks as Multipliers of the Quantity of Money}

As seen in Section 2.2, Hume applied the price-specie-flow mechanism in the case of the overnight story and exogenous supply of money. However, what should have been restricted to a hypothetical experiment, positing a miraculous increase in the quantity of metallic currency, was considered by Hume himself in the end as possible in reality within the banking system. As the Section 3.2 will examine, in contrast to the Cantillon's analysis, Hume was convinced that banks 'multiply' money and could artificially supply any monetary quantity: indeed, he described bank notes as if they were not convertible and concluded that their effects on prices are similar. In addition, Hume seemed to grant analytical importance to the form of bank liabilities: he described the technique of 'bank-credit' that consisted of an advance on current account (Discourses, p. 319) and, without explanation, did not explicitly apply his quantity approach to demand deposits as he did to bank notes.

The Discourses sustain a proposition, termed here the quantity approach of banking, which contains three postulates. First, convertible bank notes are considered equivalent to specie money. Moreover, bank notes such as issued by the Scottish

banks during Hume's time are amalgamated with paper money of the kind issued in the colonies - the same term 'paper credit' is systematically employed for the two 
kinds of issue. This analytical confusion led Hume to believe that both could raise the quantity of money and have a similar effect on prices (Discourses, pp. 318-319). Second, banks carry out 'the multiplication of money' and by contrast 'the Bank of Amsterdam did not multiply money' (Hume, 1758 [1962], p. 441) insofar as it was believed that its liabilities were fully backed by reserves. Third, bank notes as well as inconvertible paper money alter prices in proportion to their quantity. Thus, the following passage from 1752 perfectly sums up the three points of the quantity approach of banking in the case of the specie regime: '[banks] render paper equivalent to money, circulate it throughout the whole state, make it supply the place of gold and silver, raise proportionably the price of labour and commodities, and by that means either banish a great part of those precious metals, or prevent their farther encrease'. (Discourses, p. 316). Hume fully adhered to the quantity theory and applied the price-specie-flow mechanism to bank notes, which purge a great part of the precious metals from the state. In the 1752 edition, Hume vehemently argued against bank notes, supposed to create a lot of inconveniences and to set the pricespecie-flow mechanism in motion (Discourses, pp. 284, 317-318). In the 1764 edition, Hume's opinion on bank notes is less straightforward. In a supplementary passage (Discourses, p. 318), which contains neither theoretical proof, nor normative conclusion, it is 'confessed' that their advantages could be superior to their disadvantages and a 'right use of paper-money' (here, bank notes) is recommended. However, from a theoretical point of view, Hume did not attempt to amend the pricespecie flow mechanism applied to bank notes. He even repeated it in 1764 (Discourses, p. 320) by considering again that 'besides giving too great facility to credit, which is dangerous', bank-issuing inventions 'banish the precious metals'.

These three postulates of the quantity approach of banking may be analysed in the light of the Cantillon's theory of banking. By stating that 'paper' issued by banks is 'equivalent to money', Hume failed to see the analytical distinction held by Cantillon between money and demand debts whatever their form. Since the demand debts accelerate the circulation of money, they may not be considered as equivalent, just as the wind cannot be the equivalent of the sailboat, and any aggregation between money and demand debts makes no sense. Furthermore, by stating that bank notes 'circulate throughout the whole state', Hume failed to perceive that the note exchange and clearing mechanism depicted early on by Cantillon works like a sponge that catches and absorbs all bank notes in excess and annuls their circulation. Finally, Hume disregarded Cantillon's theoretical outcome which implies that banks issue demand debts as long as their marginal cost does not exceed the interest on loans; that the supply of demand debt is endogenously determined by the demand of them and is constrained in the immediate short term by convertibility; and finally that no relation between quantity of demand debts and prices may arise.

In accordance with his own theory of bank note issue, Hume recommended the $100 \%$ reserve requirement and believed that this was the case of the Bank of 
Amsterdam (Discourses, pp. 284-285): 'it must be allowed, that no bank could be more advantageous, than such a one as locked up all the money it received, and never augmented the circulation coin, as is usual, by returning part of its treasure into commerce'. Hume was a forerunner of the Currency School with regard to the analysis of the bank issue, for a twofold reason. First, he made the factual claim that bank notes enter into the monetary aggregate, mentioned the money multiplier principle, and applied the quantity theory to bank notes to conclude with the pricespecie-flow mechanism. Second, he advocated the $100 \%$ reserve rule, that is, the currency principle.

It is noteworthy that, from a methodological viewpoint, Hume's thought on money and banking is equivocal. In the case of the metallic money (Discourses, p. 311), the overnight story was justified in order to prove the impossibility of disequilibrium of the balance of trade with 'general argument' (the hypothetical experiment) rather than to 'refute by particular detail' (the state of the exports and imports in Britain). In the case of bank issuance (Discourses, p. 320), by contrast, there was a need to find proof of arguments with 'particular detail' (the comparison of the past and present state of Scotland). The reference to empirical or historical proof could reveal some insufficiencies in his theory of bank issue or, at least, could be misleading.

Indeed, the Scottish banking system at the time of Hume suffered from issuance of very small denominations and above all from a widespread use of the option clause (Checkland, 1975; Munn, 1975, 1981; Dowd, 1988). The option clause gave to an issuing bank the opportunity to transform bank notes that were convertible on demand into short-term bills bearing interest. It was mainly used by Scottish banks in 1750-1760 as an answer to an aggressive strategy, 'note duelling', whereby banks attempted to accumulate rival bank note holdings and to present them en masse so as to siphon off the reserve of the target banks. In order to alleviate a drastic fall of reserve that would have threatened their liquidity, target banks implemented the option clause, which allowed them to defer convertibility on demand, for 6 months, and consequently pay an interest of $5 \%$ on the deferred bills. Thus, demand debts became short-time obligations and their value fluctuated just like any other term bills, according to the solvency risk. The use of the option clause signalled the liquidity problem of the target bank publicly. It ensued that the option clause might have given the illusion that bank notes could fall in value due to the quantity in excess. In other words, the same piece of paper transformed into term bills that dropped in value could create confusion among the public and cause the theoretician to conclude that the bank note issued was 'depreciated' in relation to specie; another step could be easily overcome by adding that the 'depreciation' of the bills could be in proportion to the quantity in excess. The illusion created by the option clause possibly explains why Hume confused convertible bank notes, deferred bills and, finally, inconvertible paper money; why he used the similar reasoning when he dealt with notes issued by Scottish bank (under the option clause or not) as well as with inconvertible paper 
money created in the colonies. It is interesting to note that Robert Peel, in his speech at the British parliament in May 1844 (Peel, 1844), restated the same misapprehension resulting from a confused analysis of the option clause.

In contrast, Adam Smith was plainly aware of the distinct feature of bank notes convertible at face value on demand, short-term bills under the option clause and inconvertible paper money. Smith (1763) had judiciously advocated the prohibition of the option clause so as to avoid mix-ups among an unsatisfied public. The option clause prohibition was voted by the Scottish Parliament in 1765 and then gave a strong incitement to Scottish banks to cooperate, based on a system of mutual acceptance and regular clearing of bank notes. The mutual and regular acceptance of bank notes then substituted for note duelling and it progressively took place in the 1770s through bilateral arrangements that the Bank of Scotland and Royal Bank of Scotland had been experimenting with since the early 1750s, and even through multilateral arrangements that Smith could have begun to observe at the end of the 1770s. Once it had been implemented and generalised within the Scottish banking system, the practice of note acceptance and clearance allowed bank notes and more generally, demand debts, to be routinely exchanged at face value and on demand; and it lessened the raison d'être of the option clause and its corresponding discount on deferred bills. The illusion that convertible bank notes could fall in value disappeared with the option clause, but not the theoretical confusion that had appeared with it.

\section{Conclusion}

The 'classical' monetary theory expounds one principle of regulation for each kind of issue: the cost-of-production theory explains the value of metallic money, the law of reflux explains the regulation of issues of demand debts and the quantity theory is only applied in the case of debasement and cautiously in the case of inconvertible paper money. In this respect, after Cantillon, Smith (1776) and the Banking School (Mill, 1844; Tooke, 1844, 1848; Fullarton, 1845) belong to the classical monetary theory. In contrast, the 'quantity' monetary theory reasons in terms of the aggregation of all kinds of monies and then applies the causality and proportionality postulates irrespective of the kind of issue, the monetary aggregate, or the monetary regime. When Hume (Discourses, p. 281) stated that 'prices of commodities are always proportioned to the plenty of money' (added italics), he applied the quantity theory to miraculous supply of metallic currency, the multiplication of bank notes as well as the inconvertible paper money. Ricardo $(1810,1816,1817)$ is often interpreted in literature as a quantity theorist and the Currency School (Joplin, 1844; Loyd, 1840, 1844 ; Torrens, 1844,1848 ) clearly supported the quantity theory and merely posited the case of exogenous money. Therefore, continuities may be found within the two theoretical traditions. Within the classical monetary theory, Smith and the authors of 
the Banking School held the cost-of-production theory of the value of money and challenged the Humean and Currency School analyses of bank notes by further developing the law of reflux in general. Within the quantity theory, Ricardo and more significantly the Currency School repeated the quantity approach of banking, which finally prevailed in economic analysis with regard to bank notes during the 19th century and bank deposits during the 20th century.

\section{Notes}

1. On Cantillon and the Essai sur la Nature du Commerce en Ge 'ne 'ral (written around 1730 and first published in 1755, Higgs' edition in 1931 (Cantillon, 1755 [1931]), hereafter Essai), see Jevons (1881), Higgs (1891, 1892), Hayek (1931, 1932), Rist (1938 [1940]), Salleron (1952), Sauvy (1952), Spengler (1954), Bordo (1983), Murphy (1986), Brewer (1988, 1992), Thornton (2007a, 2007b), Gillard (2011), Van der Berg (2012). On David Hume as a monetary economist and the Political Discourses (first edition in 1752, Miller's edition in 1985 (Hume, 1752 [1985]), hereafter Discourses), see Rotwein (1955), Duke (1979), Fausten (1979), Mayer (1980), Samuelson (1980), Rashid (1984), Perlman (1987), McGee (1989), Berdell (1995), Gatch (1996), Cesarano (1998), Schabas (2001, 2008), Wennerlind (2001, 2005, 2008), Caffentzis (2001, 2008), Dimand (2004), Paganelli (2006, 2007, 2009), Desmedt (2008), Schabas and Wennerlind (2011).

2. The interpretation considering Cantillon and Hume as proponents of the pricespecie-flow mechanism may be found in the following literature. Regarding Cantillon, see Angell (1926, pp. 213-214), Viner (1937, pp. 86, 292), Wu (1939, pp. 68-69), Schumpeter (1954, p. 223, 316, 331, 365-367), Patinkin (1956, p. 375), Vickers (1959, pp. 210-211), Fetter (1965, p. 4), Petrella (1968, p. 365), O'Brien (1975 [2004], p. 171), Brewer (1988, p. 453; 1992, p. 186), Thornton (2007a, pp. 460-461). Laidler (1988, pp. 78, 92) claims that the quantity theory took a 'classical form' with the work of Cantillon, whose treatment of the quantity theory would have anticipated that of David Hume and his price-specie-flow mechanism. Concerning Hume, see Angell (1926, p. 47, 51, 214), Wu (1939, pp. 76-78), Patinkin (1956, p. 375), Vickers (1959, p. 236-237), Sekine (1973, p. 277), O’Brien (1975 [2004] [2004, p. 171]), Fausten (1979, p. 664), Samuelson (1980, pp. 146-147), Murphy (1986, pp. 270-272; 2009, pp. 105-106), Berdell (1995, p. 1207), Thornton (2007a, pp. 460-461), Arnon (2011, pp. 17-19).

3. The interpretation considering Cantillon and Hume as proponents of the monetary approach to the balance of payments may be found in the following literature. Regarding Cantillon, see Bordo (1983, pp. 244-246), Murphy (1986, p. 272). Notwithstanding, Murphy (2009, pp. 88-89) adds that a passage of the Essai (pp. 
165-167) 'represents a clear statement of the self-adjustment price specie flow mechanism'. Concerning Hume, see Johnson (1972, pp. 229-230; 1976, p. 274), Cesarano (1998, pp. 182-184), Wennerlind (2005, p. 230).

4. In the secondary literature, Holtrop (1929, pp. 506-507) followed by Rist (1938 [1940], pp. 38-39, 69-71) underlined the importance of Cantillon's banking approach of circulation. Monroe (1923, p. 256), Wu (1939, pp. 65-66), Spengler (1954, p. 414), Murphy (1986, pp. 276-277) and Brewer (1992, p. 103) mention it in passing. Schumpeter (1954, pp. 319-321) explicitly attempted to refute it. Vickers $(1959$, p. 215) claims that Cantillon's conception of the function of banking relies on 'a virtually complete oversight of the importance of the moneycreating function' and Bordo (1983, pp. 237, 256) that Cantillon 'was unaware of the role of banks as money creators through the bank multiplier process'. In fact, Cantillon provided an alternative theory to the money-multiplier principle. As Gillard (2011) points out, the approach of bank issuing in the Essai is not consistent with the quantity approach of the money multiplier.

5. In the secondary literature, Hume's quantity approach of banking has been less commented than that of the overnight story. Petrella (1968, pp. 372-373) and Paganelli (2006, pp. 541-542) mention that, for Hume, bank notes are supposed to exert strong inflationary pressures. Caffentzis (2001, pp. 320-322; 2008, pp. 147149) questions Hume's supposed hostility to paper credit without specifying however whether bank notes or inconvertible paper money were concerned. Wennerlind (2005, pp. 234-235) indicates that Hume's analysis of bank issuing fits into the model with an artificial and exogenous expansion of money. Desmedt (2008, pp. 18-19) links Hume's opinion on bank notes with the monetary disorder in Scotland during the 1750s. 


\section{References}

Angell, J.W. (1926) The Theory of International Prices. Cambridge: Harvard University Press.

Arnon, A. (2011) Monetary Theory and Policy from Hume and Smith to Wicksell: Money, Credit, and the Economy. Cambridge: Cambridge University Press.

Berdell, J.F. (1995) The present relevance of Hume's open-economy monetary dynamics. Economic Journal 105(432): 1205-1217.

Blaug, M. (1995) Why is the quantity theory the oldest surviving theory in economics. In M. Blaug (ed.), The Theory Quantity: From Locke to Keynes and Friedman (pp. 27-49). Aldershot: Edward Elgar.

Bordo, M.D. (1983) Some aspects of monetary economics of Richard Cantillon. Journal of Monetary Economics 12(2): 235-258.

Brewer, A. (1988) Cantillon and mercantilism. History of Political Economy 20(3): 447-460.

Brewer, A. (1992) Richard Cantillon: Pioneer of Economic Theory. London: Routledge.

Caffentzis, C.G. (2001) Hume, money and civilization: or, why was Hume a metallist? Hume Studies 27(2): 301-335.

Caffentzis, C.G. (2008) Fiction or counterfeit? David Hume's interpretations of paper and metallic money. In M. Schabas and C. Wennerlind (eds.), David Hume's Political Economy (pp. 146-167). London: Routledge.

Cantillon, R. (1755 [1931]) Essai sur la Nature du Commerce en Général. H. Higgs (ed.). London: Macmillan.

Cesarano, F. (1998) Hume's specie-flow mechanism and classical monetary theory: an alternative interpretation. Journal of International Economic 45(1): 173-186.

Checkland, S.G. (1975) Scottish Banking: A History, 1695-1973. Glasgow: Collins.

Desmedt, L. (2008) L'Analyse de la monnaie et de la finance par David Hume: conventions, promesses et reégulations. Revue Economique 59(1): 51-73.

Dimand, R.W. (2004) David Hume on Canadian paper money: an overlooked contribution. Journal of Money, Credit, and Banking 37(4): 783-787.

Dowd, K. (1988) Option clauses and the stability of a laisser faire monetary system. Journal of Financial Services Research 1(4): 319-333.

Duke, M. (1979) David Hume and monetary adjustment. History of Political Economy 11(4): 572-587.

Fausten, D.K. (1979) The Humean origin of the contemporary monetary approach to the balance of payments. Quarterly Journal of Economics 93(4): 655-673.

Fetter, F.W. (1965) The Development of British Monetary Orthodoxy, 1797-1875. Cambridge, Harvard University Press.

Frenkel J.A. and Johnson H.G. (1976) The monetary approach to the balance of payments: essential concepts and historical origins. In J.A. Frenkel and H.G. Johnson (eds.), The Monetary Approach to the Balances of Payments (pp. 21-45). London: Allen and Unwin. 
Fullarton, J. (1845) On the Regulation of Currencies (Second edn). London: John Murray.

Gatch, L. (1996) To redeem metal with paper: David Hume's philosophy of money. Hume Studies 22(1): 169-191.

Gillard, L. (2011) Le statut de la monnaie dans le Traité de Montchrestien et dans l'Essai de Cantillon. In A. Guery (ed.), Montchrestien et Cantillon. Le commerce et l'émergence d'une pensée économique (pp. 333-370). Lyon: ENS Editions.

Glasner, D. (1985) A reinterpretation of the classical monetary theory. Southern Economic Journal 52(1): 46-67.

Glasner, D. (1989) On some classical monetary controversies. History of Political Economy 21(2): 201-229.

Glasner, D. (2000) Classical monetary theory and the quantity theory. History of Political Economy 32(1): 39-59.

Hayek, F.A. (1931 [1985]) Richard Cantillon. Introduction of the German translation of the Essai. Jena: Fischer. Journal of Libertarian Studies 7(2): 217-247.

Hayek, F.A. (1932) Review: Essai sur la nature du commerce en général by Richard Cantillon. Economic Journal 42(165): 61-63.

Higgs, H. (1891) Richard Cantillon. Economic Journal 1(2): 262-291.Higgs, H. (1892) Cantillon's place in economy. Quarterly Journal of Economics 6(4): 436456.

Holtrop, M.W. (1929) Theories of the velocity of circulation of money in earlier economic literature. Economic History, 4(January): 503-524.

Hume, D. (1749 [1955]) Letter to Montesquieu, April 10, 1749. In E. Rotwein (ed.), David Hume: Writings on Economics (pp. 187-189). Madison: University of Wisconsin Press.

Hume, D. (1750 [1955]) Letter to Oswald, November $1^{\text {th }}$, 1750. In E. Rotwein (ed.), David Hume: Writings on Economics (pp. 197-199). Madison: University of Wisconsin Press.

Hume, D. (1752 [1985]) Political Discourses, in Essays, Moral, Political, and Literary. E.F. Miller (ed.). Indianapolis: Liberty Fund.

Hume, D. (1758 [1962]) New Hume letters to Lord Elibank, 1748-1776. Texas Studies in Literature and Language 4(1): 431-460.

Hume, D. (1769 [1955]) Letter to Morellet, July 10, 1769. In E. Rotwein (ed.), David Hume: Writings on Economics (pp. 214-215). Madison: University Press of Wisconsin.

Jevons, W.S. (1881) Richard Cantillon and the nationality of political economy. Contemporary Review 39(January): 61-80.

Johnson, H.G. (1972) Further Essays in Monetary Economics. London: Allen and Unwin.

Johnson, H.G. (1976) The monetary theory of balance-of-payments policies. In J.A. Frenkel and H.G. Johnson (eds.), The Monetary Approach to the Balances of Payments (pp. 262-286). London: Allen and Unwin. 
Joplin, T. (1844) Currency Reform: Improvement not Depreciation. London: Pelham Richardson.

Laidler, D. (1988) British monetary orthodoxy in the 1870s. Oxford Economic Papers 40(1): 74-109.

Locke, J. (1691 [1823]) Some Considerations of the Consequences of Lowering of Interest, and Raising the Value of Money, in a Letter to a Member to Parliament, in The Works of John Locke, Vol. 5. London: Thomas Tegg.

Loyd, S.J. (1840) Remarks on the Management of the Circulation and on the Condition and Conduct of the Bank of England. London: Pelham Richardson.

Loyd, S.J. (1844) Thought on the Separation of the Departments of the Bank of England. London: Pelham Richardson.

Marx, K. (1859 [1970]) A Contribution to the Critique of Political Economy. New York: International Publishers.

Mayer, T. (1980) David Hume and monetarism. Quarterly Journal of Economics 95(1): 89-101.

McGee, R.W. (1989) The economic thought of David Hume. Hume Studies 15(1): 184-204.

Mill, J.S. (1844) The currency question. Westminster Review 41(March-June): 579_ 598.

Monroe, A.E. (1923) Monetary Theory before Adam Smith. Cambridge: Harvard University Press.

Munn, C.W. (1975) The origins of the Scottish note exchange. Three Bank Review 107: 45-60.

Munn, C.W. (1981) The Scottish Provincial Banking Companies, 1747-1864. Edinburgh: John Donald.

Murphy, A.E. (1986) Richard Cantillon: Entrepreneur and Economist. Oxford: Oxford University Press.

Murphy, A.E. (2009) The Genesis of Macroeconomics: New Ideas from Sir William Petty to Henry Thornton. Oxford: Oxford University Press.

Niehans, J. (1978) The Theory of Money. Baltimore: Johns Hopkins University Press.

Niehans, J. (1987) Classical monetary theory, new and old. Journal of Money, Credit, and Banking 19(4): 409-424.

Niehans, J. (1990) A History of Economic Theory: Classic Contribution, 1720-1980. Baltimore: Johns Hopkins University Press.

O'Brien, D.P. (1975 [2004]) The Classical Economists Revisited. Princeton: Princeton University Press.

O'Brien, D.P. (1995) Long-run equilibrium and cyclical disturbances: the currency and banking controversy and monetary control. In M. Blaug (ed.), The Theory Quantity: From Locke to Keynes and Friedman (pp. 50-79). Aldershot: Edward Elgar.

Paganelli, M.P. (2006) Hume and endogenous money. Eastern Economic Journal 32(3): 533-547. 
Paganelli, M.P. (2007) The good policy of the magistrate: deflation as a policy option in David Hume's economic essays. History of Economic Ideas 15(3): 9-25.

Paganelli, M.P. (2009) David Hume on monetary policy: a retrospective approach. Journal of Scottish Philosophy 7(1): 65-85.

Patinkin, D. (1956) Money, Interest, and Prices. Evanston: Row and Peterson.Peel, R. (1844) Speeches of Sir Robert Peel in the House of Commons, May 6th and 20th 1844, on the Renewal of the Bank Charter, and the State of the Law respecting Currency and Banking. London: John Murray.

Perlman, M. (1987) Of a controversial passage in Hume. Journal of Political Economy 95(2): 274-289.

Petrella, F. (1968) Adam Smith's rejection of Hume's price-specie-flow mechanism: a minor mystery resolved. Southern Economic Journal 34(3): 365-374.

Petty, W. (1664 [1899]) Verbum Sapienti. In C.H. Hull (ed.), The Economic Writings of Sir William Petty, Vol. 1 (pp. 99-120). Cambridge: Cambridge University Press.

Petty, W. (1682 [1899]) Quantulumcunque concerning money. In C.H. Hull (ed.), The Economic Writings of Sir William Petty, Vol. 2 (pp. 437-448). Cambridge: Cambridge University Press.

Rashid, S. (1984) David Hume and eighteenth-century monetary thought: a critical comment on recent views. Hume Studies 5(2): 156-164.

Ricardo, D. (1810 [1951]) The high price of bullion, a proof of the depreciation of bank notes. In P. Sraffa (ed.), Works and Correspondence, Vol. 3. Cambridge: Cambridge University Press.

Ricardo, D. (1811 [1951]) Reply to Mr. Bosanquet's practical observations on the report of the Bullion Committee. In P. Sraffa (ed.), Works and Correspondence, Vol. 3. Cambridge: Cambridge University Press.

Ricardo, D. (1816 [1951]) Proposals for an economical and secure currency. In P. Sraffa (ed.), Works and Correspondence, Vol. 4. Cambridge: Cambridge University Press.

Ricardo, D. (1817 [1951]) On the principles of political economy and taxation. In P. Sraffa (ed.), Works and Correspondence, Vol. 1. Cambridge: Cambridge University Press.

Rist, C. (1938 [1940]) A History of Monetary and Credit Theory from John Law to the Present Day. London: Macmillan.

Rotwein, E. (1955) Introduction to David Hume: Writings on Economics. Madison: University of Wisconsin Press.

Salleron, L. (1952) Note Pre' liminaire. In R. Cantillon, Sur la nature du commerce en général (pp. 1xv-1xxii). Paris: Institut National d'Etudes De' mographiques.

Samuelson, P.A. (1980) A corrected version of Hume's equilibrating mechanism for international trade. In J. Chipman and C. Kindleberger (eds.), Flexible Exchange Rates and the Balance of Payments: Essays in Memory of Egon Sohmen (pp. 141158). Amsterdam: North Holland. 
Sauvy, A. (1952) Actualité de Cantillon. In Richard Cantillon, Sur la nature du commerce en général (pp. i-xii). Paris: Institut National d'Etudes Démographiques.

Schabas, M. (2001) David Hume on experimental natural philosophy, money, and fluids. History of Political Economy 33(3): 411-435.

Schabas, M. (2008) Temporal dimension in Hume's monetary theory. In M. Schabas and C. Wennerlind (eds.), David Hume's Political Economy (pp. 127-145). London: Routledge.

Schabas, M. and Wennerlind, C. (2011) Hume on money, commerce, and the science of economics. Journal of Economic Perspectives 25(3): 217-230.

Schumpeter, J.A. (1954) History of Economic Analysis. London: Allen and Unwin.

Sekine, T.T. (1973) The discovery of international monetary equilibrium by Vanderlint, Cantillon, Gervaise and Hume. Economia Internazionale 26(2): 262282.

Senior, N.W. (1840) Three Lectures on the Value of Money. London: Fellowes.

Skaggs, N.T. (1991) John Fullarton's law of reflux and central bank policy. History of Political Economy 23(3): 457-480.

Skaggs, N.T. (1994) The place of J.S. Mill in the development of British monetary orthodoxy. History of Political Economy 26(4): 539-567.

Skaggs, N.T. (1995) Henry Thornton and the development of classical monetary economics. Canadian Journal of Economics 28(45): 1212-1227.

Smith, A. (1763 [1993]) Thoughts concerning banks, and the paper-currency of Scotland. The Scots Magazine November 1763. History of Political Economy 25(2): 274-278.

Smith, A. (1776 [1937]) The Wealth of Nations. E. Cannan (ed.). New York: Modern Library.

Spengler, J.J. (1954) Richard Cantillon: first of the modern. Journal of Political Economy 62(4): 281-295, 62(5): 406-424.

Thornton, H. (1802 [1939]) An Enquiry into the Nature and Effects of the Paper Credit of Great Britain. F.A. Hayek (ed.). London: Allen and Unwin.

Thornton, M. (2007a) Cantillon, Hume, and the rise of antimercantilism. History of Political Economy 39(3): 453-480.

Thornton, M. (2007b) Was Richard Cantillon a mercantilist? Journal of the History of Economic Thought 29(4): 417-435.

Tooke, T. (1844) An Inquiry into the Currency Principle (Second edn). London: Longmans.

Tooke, T. (1848) A History of Prices and of the State of the Circulation, 1839-1847, Vol. 4. London: Longmans.

Torrens, R. (1844) An Inquiry into the Practical Working of the Proposed Arrangements for the Renewal of the Charter of the Bank of England, and the Regulation of the Currency (Second edn). London: Smith and Elder.

Torrens, R. (1848) The Principles and Practical Operation of Sir Robert Peel's Bill 
of 1844 Explained, and Defended against the Objections of Tooke, Fullarton, and Wilson. London: Longmans.

Van der Berg, R. (2012) Richard Cantillon's early monetary views? Economic Thought 1(1): 48-79.

Vickers, D. (1959) Studies in the Theory of Money, 1690-1776. London: Peter Owen. Viner, J. (1937) Studies in the Theory of International Trade. London: Harper.

Wennerlind, C. (2001) The link between David Hume's Treatise of Human Nature and his fiduciary theory of money. History of Political Economy 33(1): 139-160.

Wennerlind, C. (2005) David Hume's monetary theory revisited: was he really a quantity theorist and an inflationist? Journal of Political Economy 113(1): 223237.

Wennerlind, C. (2008) An artificial virtue and the oil of commerce: a synthetic view of hume's theory of money. In M. Schabas and C. Wennerlind (eds.), David Hume's Political Economy (pp. 105-126). London: Routledge.

Wu, C.Y. (1939) An Outline of International Price Theories. London: Routledge. 
Appendix: The 'classical' and 'quantity' traditions

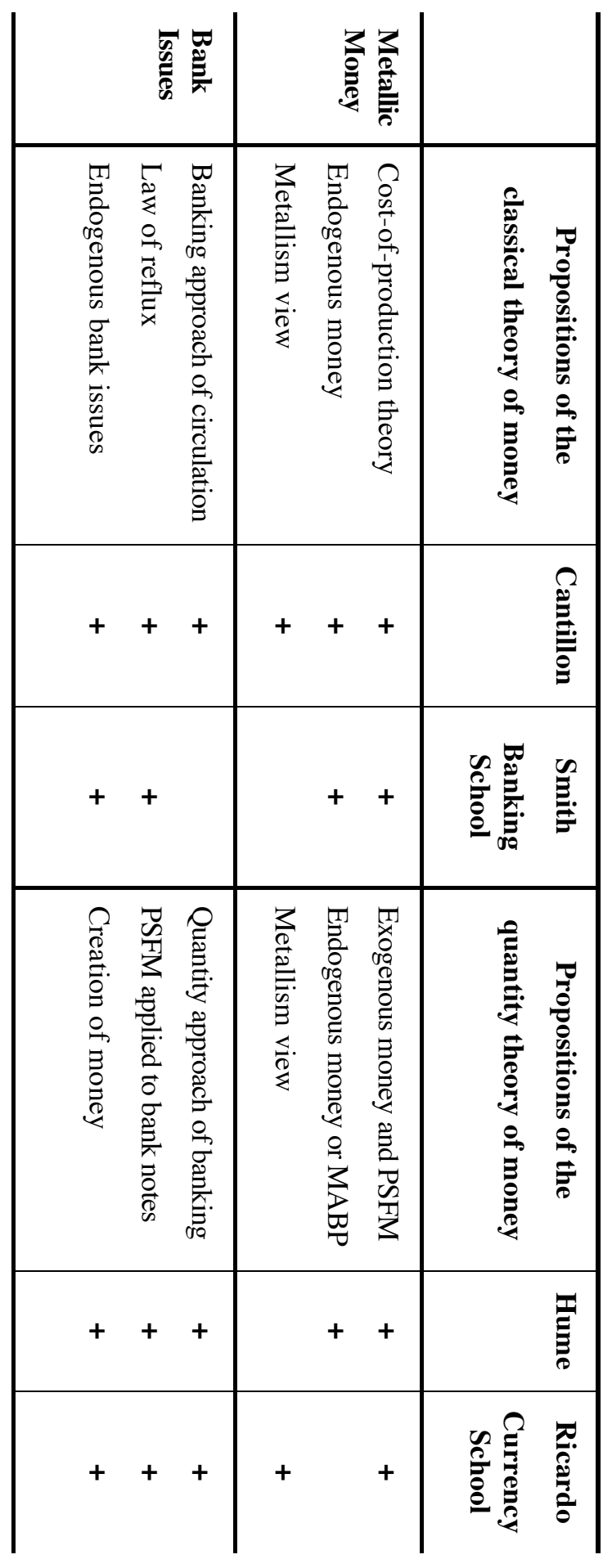

